\title{
Forespørsler om tilgang til helseopplysninger fra Folkehelseinstituttet
}

\author{
Nils Jørgen Langtvedt \\ Avdeling for helsestatistikk, Nasjonalt folkehelseinstitutt, Postboks 4404 Nydalen, 0403 Oslo \\ Telefon: 23408155 E-post: nils.langtvedt@fhi.no
}

\begin{abstract}
SAMMENDRAG
Nasjonalt folkehelseinstitutt administrerer og er databehandlingsansvarlig for en rekke helseregistre som mange forskere, helseadministratorer og andre, både internt og eksternt, er interesserte i å få opplysninger fra. Flere av registrene fra helseundersøkelser har en biobank knyttet til seg. Det er gitt en rekke lover og forskrifter som skal sikre forsvarlig tilgang til slike registre. Artikkelen går gjennom de mest sentrale vilkårene for tilgang til helsedata og hvilke vurderinger Folkehelseinstituttet gjør med hensyn til bl.a. taushetsplikt og konsesjonsplikt når det søkes om tilgang til data fra ulike typer registre.
\end{abstract}

Nasjonalt folkehelseinstitutt administrerer og eier en rekke helseregistre som flere er interesserte i å få opplysninger fra; det være seg forskere, helseadministratorer og andre. Noen av disse registrene har en biobank knyttet til seg.

Registrene kan kategoriseres i to typer:

1) "sentrale helseregistre", som er registre som formelt, om enn ikke i praksis, ble opprettet i lov av 18. mai $2001 \mathrm{nr} .24 \mathrm{om}$ helseregistre og behandling av helseopplysninger $\S 8$ : Dødsårsaksregisteret, Medisinsk fødselsregister, Kreftregisteret, System for vaksinasjonskontroll (SYSVAK), MSIS/Tuberkulose, og Reseptregisteret; og

2) "samtykkebaserte helseundersøkelser" (regionale helseundersøkelser: Conor; og Mor og barnundersøkelsen; Miljømessige årsaker til diabetes type 1 (MIDIA); Tvillingundersøkelsen).

For en nærmere beskrivelse, vises til "Oversikt over helseregistre i Norge".

Hvordan de sentrale helseregistrene kan brukes, følger av formålsparagrafen i forskriften til det aktuelle registeret. I tillegg til bruk knyttet direkte opp mot begrunnelsen for å etablere registeret, kan registeret som regel også "...behandles til styring, planlegging og kvalitetssikring av helsetjenesten og helseforvaltningen, utarbeiding av statistikk og til forskning", sml. MFR-forskriften $\S 1-3$ siste ledd.

Registre som føres i de samtykkebaserte helseundersøkelsene, er regulert av konsesjoner gitt av Datatilsynet, og disse er i første rekke etablert for forskning, men brukes også til statistikk og helseovervåkning.

Denne artikkelen tar for seg helseopplysningene brukt til forskning, og hvordan forskere kan få tilgang til opplysninger fra Folkehelseinstituttets registre.

Registrene inneholder helseopplysninger, dvs. beskrivelser av de registrerte personenes helse i ulike aspekter og situasjoner. Det som imidlertid er det sentrale spørsmålet når det gjelder forskeres rett til opplysninger, er formen på opplysningene som etterspørres, og da menes det om forespørselen gjelder

1. anonyme opplysninger;

2. avidentifiserte opplysninger; eller

3. personidentifiserbare opplysninger.

Reglene for tilgang til helseopplysninger finnes i

a) helsepersonelloven (taushetsplikt) og forvaltningsloven (dispensasjon fra taushetsplikt);

b) helseregisterloven med forskrifter;

c) personopplysningsloven med forskrifter; og

d) konsesjoner fra Datatilsynet.

Hvilke regler som kommer til anvendelse på en konkret forespørsel, avhenger av

1. hvilket register det etterspørres opplysninger fra; og

2. hvilken type opplysninger som etterspørres.

Fremstillingen nedenfor tar utgangspunkt i registerforskriftenes kap. 3, som er likelydende for alle de sentrale helseregistrene, og Datatilsynets konsesjon for "Landsomfattende helseundersøkelser" og "Mor og barn-undersøkelsen" (se "Oversikten over helseregistre i Norge" punkt 4.1 og 4.2) som i hovedtrekk inneholder tilsvarende vilkår.

\section{GENERELLE VILKÅR FOR UTLEVERING AV HELSEOPPLYSNINGER}

Disse vilkårene gjelder alle forespørsler om informasjon.

\subsection{Formål}

Hvert register har sitt definerte formål, dvs. hvilke forskningstema opplysningene kan brukes til. Formålet følger av bestemmelser i forskriftene til det enkelte register eller i konsesjonen gitt av Datatilsynet. Utlevering av opplysninger kan ikke skje til formål som ikke omfattes av formålsformuleringen i forskrift eller konsesjon. I tillegg må den behandlingen av opplysningene som utleveringen skal tilgodese, være "ubetenkelig 
ut fra etiske hensyn" (eksempelvis rasistisk motivert), herunder at forskningen er berettiget og forsvarlig.

\subsection{Taushetsplikten}

For å få opplysninger fra ett (eller flere sammenstilte) helseregister må det avklares om det er nødvendig med nytt samtykke eller dispensasjon fra taushetsplikten. Før utlevering kan skje, vil Folkehelseinstituttet alltid kreve at dette er i orden.

Hvis utlevering til en konkret undersøkelse ligger innenfor et allerede gitt samtykke, er dette normalt tilstrekkelig. I motsatt fall avklares forholdet til taushetsplikten enten ved at det innhentes nytt samtykke fra de registrerte eller dispensasjon fra taushetsplikten.

Et samtykke er en frivillig, uttrykkelig og informert erklæring fra den registrerte om at han eller hun godtar behandling av helseopplysninger om seg selv, helseregisterloven $\S 2 \mathrm{nr}$. 11. Samtykket bør være skriftlig. Samtykket må omfatte hvilke (type) opplysninger som innhentes, kilde og hva de skal brukes til, eventuelt om og hvilke andre registre de skal kobles til.

Dispensasjon fra taushetsplikten gis av et organ som er overordnet registereieren. Når det gjelder helseopplysninger er dette Helsedepartementet, men myndigheten til å gi dispensasjon er delegert til Sosial- og helsedirektoratet.

Når det gjelder sosial- eller trygdedata, er dette Sosialdepartementet. Også her er myndigheten delegert til hhv. Sosial- og helsedirektoratet og til Rikstrygdeverket.

Det er den som søker om opplysninger (mottakeren) som er ansvarlig for at det innhentes dispensasjon fra taushetsplikten.

\subsection{Konsesjonsplikt}

Dersom det utleveres helseopplysninger som direkte eller indirekte (dvs. uten kjennetegn som direkte identifiserer en person) kan knyttes til enkeltpersoner, se helseregisterloven $\S 2 \mathrm{nr}$. 1 og 2, vil det ofte oppstå et register på mottakers hånd. I så fall skal også forholdet til personopplysningsloven være avklart før utlevering kan finne sted.

Utlevering av anonyme opplysninger medfører ikke konsesjonsplikt for mottakeren.

Vær oppmerksom på at personopplysningsloven gjelder enhver "behandling" av personopplysninger. Dette omfatter all bearbeiding av opplysningene, også sammenstillingen som sådan. Med mindre annet er bestemt, betyr dette at det må innhentes tillatelse fra Datatilsynet og dispensasjon fra taushetsplikten for sammenstillingen også når resultatet av sammenstillingen skal være anonym.

På visse vilkår er enkelte behandlinger av personopplysninger fritatt fra konsesjonsplikt. Det gjelder da en egen meldeplikt. Se personopplysningsforskriften § 7-27. Alle vilkårene må være oppfylt.

Det er den som søker om opplysninger (mottakeren) som er ansvarlig for at konsesjonsspørsmålet avklares med Datatilsynet.

\section{SPESIELLE VILKÅR - FORESPØRSEL OM DATA FRA ETT ENKELT REGISTER}

\subsection{Anonyme opplysninger}

"Anonyme opplysninger" er opplysninger der navn, fødselsnummer og andre personentydige kjennetegn er fjernet, slik at opplysningene ikke lenger kan knyttes til en enkeltperson, helseregisterloven $\S 2$ nr. 3 .

Som hovedregel er det ingen restriksjoner på å utlevere anonymiserte opplysninger, f.eks. i form av statistikk. De regnes per definisjon ikke som personopplysninger, og det er verken nødvendig med dispensasjon fra taushetsplikten eller konsesjon fra Datatilsynet. Søknaden kan avgjøres av Folkehelseinstituttet.

\subsection{Avidentifiserte opplysninger}

"Avidentifiserte helseopplysninger" er helseopplysninger der navn, fødselsnummer og andre personentydige kjennetegn er fjernet, slik at opplysningene ikke lenger kan knyttes til en enkeltperson, og hvor identitet bare kan tilbakeføres ved sammenstilling med de samme opplysninger som tidligere ble fjernet, helseregisterloven $\S 2$ nr. 2 .

For at filen skal regnes som avidentifisert etter dette alternativet, må forskeren ikke ha mulighet til å gjenskape registeret i personidentifiserbar stand. Det betyr at forskeren ikke selv kan ha tilgang til opplysninger som ved sammenligning med resultatfilen gjør det mulig å føre opplysningene tilbake til enkeltpersoner.

Fødselsmåned og -år regnes ikke som personentydige kjennetegn. Hvis antallet individer i utvalget blir lite (f.eks. i en kommune/bydel), vil det vurderes konkret hvilke kjennetegn som skal fjernes.

Folkehelseinstituttet kan bestemme at det skal utleveres avidentifiserte opplysninger dersom bruken av opplysningene ligger innenfor registerets formål og er ubetenkelig ut fra etiske hensyn.

Hvis alle disse vilkårene er oppfylt, er det ikke nødvendig med dispensasjon fra taushetsplikten eller konsesjon fra Datatilsynet. Søknaden kan avgjøres av den databehandlingsansvarlige for registeret.

Hvis vilkårene ikke er oppfylt, og forskeren søker om avidentifiserte opplysninger som han/hun i praksis kan tilbakeføre til enkeltpersoner, skal søknaden behandles som personidentifiserbare data, se punkt 2.3.

\subsection{Personidentifiserbare opplysninger}

Personidentifiserbare opplysninger kan bare utleveres når mottaker har fått konsesjon fra Datatilsynet $\mathrm{og}$ fått dispensasjon fra taushetsplikten.

\section{SPESIELLE VILKÅR - FORESPØRSEL OM SAMMENSTILTE DATA (FRA FLERE REGISTRE)}

Sammenstilling (kobling) mellom sentrale helseregistre kan gjøres av den databehandlingsansvarlige for ett av registrene. 
Om sammenstilling av data fra sentrale helseregistre og samtykkebaserte helseundersøkelser, se punkt 3.3 nedenfor.

\subsection{Anonyme opplysninger}

Anonyme opplysninger fra en sammenstilling av de sentrale helseregistrene kan fritt utleveres.

\subsection{Avidentifiserte opplysninger}

Om definisjonen se punkt 2.2.

Sammenstilte, avidentifiserte opplysninger fra de sentrale helseregistrene, f.eks. fra Medisinsk fødselsregister og Dødsårsaksregisteret, kan utleveres til forskere dersom prosjektets formål ligger innenfor registrenes formål, og det er ubetenkelig ut fra etiske hensyn. Før utlevering finner sted, vil Folkehelseinstituttet slette navn, fødselsdag og personnummer.

Det er ikke nødvendig med dispensasjon fra taushetsplikten eller konsesjon fra Datatilsynet, men mottakeren av de avidentifiserte opplysningene må sende melding til Datatilsynet, helseregisterloven jf. $§ \S 29$ og-30.

Søknaden kan avgjøres av Folkehelseinstituttet.

Om sammenstilling og utlevering av opplysninger fra flere av de samtykkebaserte helseundersøkelsene, se punkt 3.3.

Hvis søkeren har egne data som ønskes koblet mot Folkehelseinstituttets registre, behandles søknaden i hht. punkt 3.3, selv om resultatfilen er avidentifisert eller anonym. Grunnen til det, er at man anser at muligheten til bakveisidentifikasjon ved sammenligning av variablene $\mathrm{i}$ resultatfilen med den egne filen, er så stor at anonymitet aldri oppnås.

\subsection{Personidentifiserbare opplysninger}

Utlevering av personidentifiserbare opplysninger kan bare skje når mottaker har konsesjon fra Datatilsynet og dispensasjon fra taushetsplikten fra Sosial- og helsedirektoratet.

Dette gjelder også om det skal utleveres anonyme eller avidentifiserte data basert på en sammenstilling av registre fra flere typer helseregistre, f.eks. CONORdata og Medisinsk fødselsregister. Grunnen til det, er at sammenstillingen uansett vil måtte baseres på en felles identifikasjon, som regel er det fødselsnummer. Siden konsesjonsplikten og kravet til dispensasjon inntrer ved "enhver behandling" av personidentifiserbare data, må disse foreligge. Kobling av eller med data som ikke er taushetsbelagte (for eksempel sosioøkonomiske data eller fødeland) må ha konsesjon, men det er ikke nødvendig med dispensasjon fra taushetsplikten.

Tillatelsene må omfatte både sammenstillingen som sådan og - eventuelt - opprettelsen av et nytt personregister. Etter helseregisterloven $\S 5$ tredje ledd er det en hovedregel om å innhente samtykke fra de registrerte før de registreres. Dette kan unnlates dersom Sosial- og helsedirektoratet gir dispensasjon fra taushetsplikten.
Hvis sammenstillingen omfatter registre som "eies" av andre, må det i tillegg til evt. konsesjon og dispensasjon fra taushetsplikten, også innhentes tillatelse fra den som eier eller administrerer opplysningene.

\section{BIOLOGISK MATERIALE}

Se artikkelen "En biobanklov til besvær?", av Anne Forus.

\section{DE REGIONALE ETISKE KOMITEER}

Forskningsprosjekter hvor det inngår forsøk på mennesker skal forelegges en av de regionale etiske komiteene (REK) til vurdering og rådgivning (www.etikkom.no/REK/). Forskning på humant biologisk materiale skal alltid forelegges REK for vurdering.

Det er fem regionale etiske komiteer; REK ØstNorge, REK Sør-Norge, REK Vest-Norge, REK MidtNorge og REK Nord-Norge.

Komiteene skal veilede og gi råd om forskningsetiske spørsmål og arbeide for å gjøre forskningsetiske prinsipper kjent (fra mandatet punkt 1).

Komiteene skal forelegges samtlige biomedisinske forskningsprosjekter hvor det inngår forsøk på mennesker og som ikke er av en slik art at det regnes som en del av vanlig etablert behandlingsprosedyre. Det gjelder både terapeutisk og ikke-terapeutisk forskning på pasienter og friske forsøkspersoner. Med biomedisinske forskningsprosjekter hvor det inngår forsøk på mennesker forstås også forskning på identifiserbart eller anonymt humant materiale og identifiserbare eller anonyme data (fra mandatet punkt 3).

Både Datatilsynet og Sosial- og helsedirektoratet forlanger vanligvis at forskningsprosjekter (som omfattes av punkt 3 i mandatet) er forelagt REK før de selv avgjør en søknad.

Det er forskerens arbeidssted som avgjør hvilken REK som skal ha meldingen.

\section{SAKSGANGEN/-BEHANDLINGEN I FOLKE- HELSEINSTITUTTET}

\subsection{Komplett søknad}

Folkehelseinstituttet kan ikke behandle en søknad om data eller biologisk materiale, før den er komplett. En komplett søknad skal sette Folkehelseinstituttet i stand til å vurdre om vilkårene for utlevering er tilstede, og vil minst måtte innholde/være vedlagt

- søkerens navn og cv (for å belyse forskningskompetanse);

- prosjektdeltakernes navn;

- søkerens tilknytning til forskningsinstitusjon;

- prosjektets/studiens/undersøkelsens formål;

- prosjektbeskrivelse som inkluderer problemstillingen(e); 
- beskrivelse av utvalget (kategorier for tid, sted og evt. eksklusjonskriterier må alltid presiseres) og hvilke variabler som skal benyttes i analysen;

- fremdriftsplan og en publiseringsplan;

- kopi av konsesjon og dispensasjon (der det er behov for det).

I løpet av høsten 2004 vil komplette retningslinjer for tilgang til data og biologisk materiale fra Folkehelseinstituttets registre være utlagt på våre hjemmesider.

\subsection{Frister}

Utlevering av data fra de sentrale helseregistrene, skjer etter de frister som er oppgitt i kap. 3 i register- forskriftene, som er 30 eller 60 dager, avhengig av hvilken type data som etterspørres.

\subsection{Vurderinger}

Før utlevering av opplysninger finner sted, vil Folkehelseinstituttet vurdere om opplysningene skal brukes til et uttrykkelig angitt formål innenfor registerets formål og om behandlingen av opplysningene er ubetenkelig ut fra etiske hensyn.

Dersom en søknad omfatter problemstillinger som dekkes av igangværende prosjekter, skal styringsgruppen e.l. for den aktuelle helseundersøkelse eller helseregister, søke å bidra til at det ikke oppstår konflikter mellom prosjektene. 